\title{
Skeletal Muscle-derived Trophic Factors Prevent Motoneurons from Entering an Active Cell Death Program in vitro
}

\author{
Joan X. Comella, Cesar Sanz-Rodriguez, Marti Aldea, and Josep E. Esquerda \\ Unit of Neuromuscular Research, Departament de Ciències Mèdiques Bàsiques, Facultat de Medicina, Universitat de \\ Lleida, E-25006 Lleida, Spain
}

\begin{abstract}
The purpose of the experiments reported here is to provide evidence that motoneurons (MTNs) isolated from chick embryo spinal cords go through an active process of cell death when deprived of trophic support in vitro. In order to analyze and characterize this process, MTNs were isolated with a metrizamide gradient technique and cultured in the presence of saturating concentrations of soluble muscle extract. When muscle extract was washed off from the cultures, MTNs entered a process of cell death that could be blocked with inhibitors of mRNA and protein synthesis. Two other additional criteria were used to define this process as an active one. First, ultrastructural analysis of MTNs dying as a consequence of muscle extract deprivation showed that some, but not all, of the MTNs displayed clear signs of apoptotic cell death. Those included cytoplasm condensation, fragmentation of chromatin, and preservation of cytoplasmic organelles. Second, internucleosomal degradation of DNA was detected in MTNs deprived of muscle extract. When DNA was analyzed by Southern hybridization techniques using digoxigenin-labeled genomic probes, a clear ladder pattern could be identified on muscle extract-deprived MTNs. The degradation of DNA upon trophic deprivation could be prevented by cycloheximide (CHX). In an attempt to characterize further the process of active cell death in MTNs, we found a time point of commitment to cell death of $\sim 10 \mathrm{hr}$ by using three different approaches: muscle extract deprivation plus readdition of muscle extract, muscle extract deprivation plus addition of $\mathrm{CHX}$, and muscle extract deprivation plus addition of actinomycin D. Moreover, we show that MTNs deprived of trophic support from muscle extract but maintained alive with $\mathrm{CHX}$ could not be rescued from cell death by readding muscle extract if $\mathrm{CHX}$ was washed off the cultures within the first $15 \mathrm{hr}$ of muscle extract deprivation. However, muscle extract alone was able to rescue MTNs that had been
\end{abstract}

\footnotetext{
Received Mar. 25, 993; revised Oct. 11, 1993; accepted Oct. 19, 1993.

J.X.C. and C.S.R. contributed equally to the elaboration of this work. We acknowledge the contribution of Anna Buj-Bello to the initial phases of this work, and we thank Dr. Eugene M. Jolinson, Jr., and colleagues of our department for the critical reading of the manuscript. We also thank Dr. C. E. Henderson, CNRSINSERM, Montpellier, France, for providing laminin and anti-SCl monoclonal antibody, and Dr. M. Epstein, University of Wisconsin, for donating anti-Ch $A T$ antiserum. We are grateful to Xavier Calomarde for helping with photographic work. This work was funded by the Ministerio de Educación y Ciencia (Grant PB90-0504) and Ajuntament de Lleida.

Correspondence should be addressed to Joan X. Comella, Unit of Neuromuscular Research, Departament Ciències Mèdiques Bàsiques, Facultat de Medicina Universitat de Lleida, Rovira Roure 44, E-25006 Lleida, Spain.

Copyright (c) 1994 Society for Neuroscience $0270-6474 / 94 / 142674-13 \$ 05.00 / 0$
}

kept alive with $\mathrm{CHX}$ for periods of time longer than $24 \mathrm{hr}$ after muscle extract deprivation. From these results we postulate that the activation of the cell death program after trophic deprivation is transient.

[Key words: motoneuron, neurotrophic factors, apoptosis, programmed cell death, neuronal death, protein synthesis inhibitors]

During embryonic development, most neuronal populations undergo a process referred to as natural or programmed cell death in which about half of neurons die (reviewed by Oppenheim, 1991). For motoneurons (MTNs) of the lumbar spinal cord of chick embryos, this process takes place in a defined period of time [embryonic days 6-10 (E6-E10)] coincident with synaptogenesis between motor nerve terminals and muscle cells and with the beginning of neuromuscular activity (Hamburger, 1975; Oppenheim and Heaton, 1975). It is now clear that neuronal populations depend on specific neurotrophic factors to survive (Barde, 1989). Death of neurons during development seems to result from the failure to obtain sufficient amounts of a neurotrophic molecule from their territory of innervation, either because of the limited quantities of factor produced and released by target tissue or because of the inability of neurons to gain access to the factor (Oppenheim, 1989; Snider and Johnson, 1989). The most extensively studied neurotrophic factor is NGF, a molecule that supports survival in vivo and in vitro of sympathetic neurons, some sensory neurons, and certain cholinergic ncurons of the CNS (Ebendal, 1992).

Recently, several groups have demonstrated that brain-derived neurotrophic factor (BDNF) and neurotrophin 3 (NT-3) are able to support the survival of MTNs. BDNF rescues MTNs from death induced by facial (Sendtner et al., 1992; Koliatsos et al., 1993) or sciatic (Yan et al., 1992) nerve lesions in neonatal rats. The effect of BDNF on rescuing MTNs of the facial nucleus after nerve lesion was also observed with NT-3, although greater doses were needed (Sendtner et al., 1992). Moreover, BDNF was able to rescue chick MTNs from naturally occurring death in vivo (Oppenheim et al., 1992). Finally, several members of the neurotrophin family that include BDNF, NT-3, and NT-5 have been shown to be neurotrophic for cultured embryonic rat MTNs at picomolar concentrations (Henderson et al., 1993).

Muscle is the natural target or innervating tissue for MTNs and it has been demonstrated that MTNs can be rescued from death, both in vitro (Dohrmann et al., 1986; Tanaka, 1987; Martinou et al., 1989; Bloch-Gallego, 1991) and in vivo (Oppenheim et al., 1988; McManaman et al., 1990; Houenou et al., 1991) by crude or partially purified muscle extracts. Although 
the mRNAs for BDNF and NT-3 are both expressed by muscle cells (Henderson et al., 1993; Koliatsos et al., 1993), it seems that most of the survival-promoting activity of muscle extract was due to a molecule similar to the fibroblast growth factor 5 (Hughes et al., 1993). Moreover, Arakawa et al. (1990) have reported that neurotrophins are not able to support the survival of chick MTNs.

The mechanisms used by neurotrophic factors to promote survival and differentiation of specific neurons are not completely understood (Chao, 1992), although in recent years a considerable amount of information has become available (Lo, 1992; Pelech and Sanghera, 1992; Roberts, 1992). Recently, several groups have approached the question of why a neuron deprived of trophic factor dies. It has been shown that the process of neuronal death after trophic deprivation is not merely a passive process but an active one that requires the synthesis of new RNA and protein (reviewed by Johnson et al., 1989; Martin and Johnson, 1991; Altman, 1992; Raff, 1992; Johnson and Deckwerth, 1993). Pharmacological inhibition of transcriptional or translational activity prevents the death in vitro of NGF-deprived sympathetic neurons (Martin et al., 1988; Edwards et al., 1991), BDNF-deprived sensory neurons, and ciliary neurotrophic factor-deprived parasympathetic neurons (Scott and Davies, 1990). These facts suggest that this is a widespread process involving neurons with completely different neurotrophic factor requirements. Moreover, there exists experimental evidence that this process takes place under completely physiological conditions since the naturally occurring death of MTNs and dorsal root ganglion neurons can be prevented in vivo by inhibition of protein or mRNA synthesis (Oppenheim et al., 1990). These results indicate that one of the main functions of a neurotrophic molecule is to suppress an active cell death program in the responding neurons (Raff, 1992; Johnson and Deckwerth, 1993).

The most characteristic features of programmed cell death or apoptosis are morphological, as originally described by Kerr et al. (1972). These include condensation of chromatin and the presence of intact organelles in dead cells and cell fragments. Another important feature of programmed cell death is the fragmentation of DNA into oligomers of oligonucleosomal-sized fragments subsequent to activation of a nonlysosomal endonuclease. When this DNA is analyzed by gel electrophoresis, a typical ladder pattern is observed (Arends et al., 1990).

In the present article we demonstrate that MTNs are dependent on trophic activities contained in soluble muscle extracts to survive in vitro. Deprivation of muscle extract resulted in the death of MTNs by a mechanism that could be blocked by preventing de novo synthesis of mRNA or protein but not by interfering with lysosomal function. Moreover, we show experimental evidence derived from electron microscopy studies suggesting that some of the morphological characteristics of the MTN death process are apoptotic. $\Lambda$ ladder pattern of DNA fragmentation was observed by Southern blotting techniques. The commitment point to death after trophic deprivation was established in $\sim 10 \mathrm{hr}$ by using different experimental approaches. Furthermore, we suggest that expression of mRNAs of death genes is transient.

Although the molecular entities from muscle tissue capable of supporting MTN survival remain poorly characterized, this neuronal population displays the same behavior upon trophic deprivation as other neuronal populations that respond to wellknown neurotrophic molecules.
Portion of this work have been published previously in abstract form (Comella et al., 1992).

\section{Materials and Methods}

Purification of motoneurons. MTNs were purified from embryonic chicken according to Arakawa et al. (1990) and Dohrmann et al. (1986) with minor modifications. Briefly, whole spinal cords were dissected from 5.5-d-old Arbor acres chick embryos from a local supplier (COPAGA) and every four spinal cords were pooled in a polystyrene tube. The dissected spinal cords were rinsed twice in dissection buffer $(137 \mathrm{~mm}$ $\mathrm{NaCl}, 2.7 \mathrm{~mm} \mathrm{KCl}, 22.2 \mathrm{~mm}$ glucose, $25 \mathrm{~mm}$ HEPES buffer $\mathrm{pH} 7.4$, $20,000 \mathrm{IU} / \mathrm{ml}$ penicillin, and $20,000 \mu \mathrm{g} / \mathrm{ml}$ streptomycin; GHEBS) and digested with $0.025 \%$ trypsin (Sigma, St. Louis, MO) for $15 \mathrm{~min}$ at $37^{\circ} \mathrm{C}$. Trypsin was inactivated by washing spinal cords twice with complete culture medium containing heat-inactivated horse serum (HIHS) (see below for composition) and cells were gently dissociated by pipetting through a Gilsun blue cone in complete culture medium. The single cell suspension was layered onto $5 \mathrm{ml}$ of Leibovitz's 15 medium (L15) (Sigma) containing $22.5 \mathrm{~mm}$ bicarbonate (L15-bic) and 3.5\% (w/v) BSA, and spun at $100 \times g$ for 5 min to remove cell debris. Cells were resuspended in GHEBS and layered onto $5 \mathrm{ml}$ of $6.8 \%(\mathrm{w} / \mathrm{v})$ metrizamide [2-(3-acetamido-5- $N$-methylacetamido-2,4,6-triiodobenzamido)-2deoxy-D-glucose; Nycomed, Oslo, Norway] in GHEBS and centrifuged at $400 \times g$ in a swinging-bucket rotor for $15 \mathrm{~min}$. The intermediate layer $(500 \mu 1$ per tube, equivalent to four spinal cords) was collected. Cells were counted with a hemocytometer and transferred to another tube containing an adequate amount of complete culture medium (L15H) whose composition was L15 supplemented with a final concentration of $18 \mathrm{~mm}$ glucose, $22.5 \mathrm{~mm}$ bicarbonate, $2.5 \mathrm{~mm}$ glutamine, $10 \%$ HIHS, and $20 \mathrm{IU} / \mathrm{ml}$ penicillin plus $20 \mu \mathrm{g} / \mathrm{ml}$ streptomycin.

Cell culture of motoneurons. MTNs were plated in 96-well culture dishes (Nunc, Roskilde, Denmark, or Corning, New York, NY) precoated with poly-DL-ornithine and laminin. The coating of culture dishes was performed as follows. First, dishes were treated for $1 \mathrm{hr}$ at room temperature with poly-DL-ornithine (MW 30,000) (Sigma) at a concentration of $1.5 \mu \mathrm{g} / \mathrm{ml}$ in borate buffer $(150 \mathrm{~mm}, \mathrm{pH} 8.5)$, rinsed twice with double-distilled water, and allowed to dry in a laminar flow hood. Thereafter, dishes were coated for a minimum of $1 \mathrm{hr}$ with laminin (3 $\mu \mathrm{g} / \mathrm{ml})$ in the $\mathrm{CO}_{2}$ incubator. Laminin was generously provided by $\mathrm{Dr}$. C. E. Henderson (CNRS-INSERM, Montpellier, France) or was purchased from Sigma. Laminin was dissolved in L15-bic. MTNs were seeded at a density of 10,000 per well and were maintained at $37.2^{\circ} \mathrm{C}$ in a saturating humidity atmosphere of $95 \%$ air, $5 \% \mathrm{CO}_{2}$.

Preparation of the denervated-muscle extract. Lower leg muscle denervation was performed on postnatal day 5 (P5) Arbor acres chicken. Following anesthesia with sodium pentobarbital (16 $\mu \mathrm{g}$ per chick in 0.2 $\mathrm{ml}$ of $0.9 \% \mathrm{NaCl}$, i.p.), the sciatic nerve was exposed at the mid-thigh level, a ligation with a 4-0 surgical silk suture was carried out, and a 5 $\mathrm{mm}$ segment was transected distal to the ligature. On P10, operated animals were examined for a complete paralysis of the denervated leg and were killed by chloroform overdose. Denervated lower leg muscles were dissected free of nonmuscle tissues, immediately frozen in liquid $\mathrm{N}_{2}$, and stored at $-80^{\circ} \mathrm{C}$ until muscle extract was prepared.

P10 chicken muscles denervated for $5 \mathrm{~d}$ (P10D5) were thawed on ice and homogenized using a Polytron apparatus at setting 4 for $2 \times 60$ sec in 5 vol of phosphate-buffered saline (PBS; $137 \mathrm{~mm} \mathrm{NaCl}, 2.7 \mathrm{~mm}$ $\mathrm{KCl}, 8.1 \mathrm{~mm} \mathrm{Na} \mathrm{HPO}_{4}, 1.5 \mathrm{mM} \mathrm{KH} \mathrm{PO}_{4}, \mathrm{pH}$ 7.4) containing $1 \mathrm{~mm}$ EDTA (Sigma), $1 \mathrm{~mm}$ benzamidine (Sigma), $1 \mathrm{~mm} N$-ethylmaleimide (Sigma), 0.1 mM phenylmethylsulfonyl fluoride (PMSF) (Sigma), and $10 \mu \mathrm{g} / \mathrm{ml}$ soybean trypsin inhibitor (Boehringer-Mannheim, Mannheim, Germany). Homogenates were centrifuged at $100,000 \times g$ for $75 \mathrm{~min}$, and the resulting supernatant was stored at $-80^{\circ} \mathrm{C}$. The resulting supernatant (MEX) was stored in $1 \mathrm{ml}$ aliquots at $-20^{\circ} \mathrm{C}$ and was spun $10 \mathrm{~min}$ at $12,000 \mathrm{rpm}$ in a microfuge prior to use. Protein concentrations were determined according to Bradford (1976) using the Bio-Rad protein assay reagent.

Evaluation of neuronal survival and apoptosis. Unless otherwise indicated, cells were cultured in the presence of a saturating concentration of MEX for $48 \mathrm{hr}$. At this time, cells were washed thoroughly and fresh medium containing supplements or drugs, as appropriate, was added. Furthermore, the number of cells bearing neurites longer than 2 cell diameters in the central area of every culture well was determined using a $20 \times$ power objective in a phasc-contrast inverted microscope. This value ranged from 20 to 70 neurons and represented our corrected $100 \%$ 
survival. Wells containing less than 20 neurons at the beginning of the experiment were not used. Counts of neurons with neurites longer than 2 cell diameters were performed every $12 \mathrm{hr}$ in the same microscopic field throughout the duration of the experiment and survival was expressed as a percentage of neuronal counts with respect to the $100 \%$ value. Values shown are the mean \pm SEM of these percentages and represent the average of six to eight wells. Each experiment was repeated at least three times.

In order to quantify the percentage of apoptotic neurons after MEX deprivation, staining of cultures with the Hoechst 33258 dye was carried out. Neurons were cultured on poly-DL-ornithine/laminin-coated glass coverslips at a density of 50,000 MTNs/coverslip in 24-well tissue culture plates (Corning). MTNs had grown for $48 \mathrm{hr}$ in the presence of saturating concentrations of MEX, were washed three times with $\mathrm{L} 15 \mathrm{H}$, and were further grown for different times in $\mathrm{L} 15 \mathrm{H}$ medium. At appropriated times, media were removed from wells and, without any washing, neurons were fixed at $4^{\circ} \mathrm{C}$ with $2.5 \%(\mathrm{v} / \mathrm{v})$ glutaraldehyde (electron microscopy grade, Bio-Rad, Cambridge, MA) in PBS for a minimum of $6 \mathrm{hr}$. Thereafter, neurons were washed three times with cold $\left(4^{\circ} \mathrm{C}\right)$ PBS and were stained for $30 \mathrm{~min}$ with $0.05 \mu \mathrm{g} / \mathrm{ml}$ Hoechst 33258 (Sigma). Coverslips containing the neurons were washed two times in PBS and were mounted in microscope slides using $70 \%(\mathrm{v} / \mathrm{v})$ glycerol in PBS as mounting medium. Stained neurons were observed with a vertical microscope equipped with epifluorescence and UV filters.

Choline acetyltransferase activity. The choline acetyltransferase (ChAT) activity present in the different cell fractions was measured by a modification of the method of Fonnum (1975). The cells were pelleted, lysed in $0.5 \%$ Triton X-100 and $10 \mathrm{~mm}$ EDTA, in $20 \mathrm{~mm}$ phosphate buffer pH 7.4, and centrifuged at $12,000 \times g$ for $5 \mathrm{~min}$. Ten microliters of the supernatant were mixed with $10 \mu \mathrm{l}$ of the assay mixture described in Fonnum (1975) and containing ${ }^{14} \mathrm{C}$-acetyl-CoA $(60 \mathrm{mCi} / \mathrm{mmol}, 50 \mu \mathrm{Ci} /$ $\mathrm{ml}$; Amersham, Buckinghamshire, UK). After a $30 \mathrm{~min}$ incubation at $37^{\circ} \mathrm{C}$, the reaction was stopped by rinsing tubes with $5 \mathrm{ml}$ of cold 10 mM phosphate buffer $\mathrm{pH} 7.4$. These $5 \mathrm{ml}$ were added to a vial containing $2 \mathrm{ml}$ of $5 \mathrm{mg} / \mathrm{ml}$ sodium tetraphenylborate in acetonitrile and $6 \mathrm{ml}$ of toluene-based scintillation mixture. Toluene-soluble radioactivity, that is, corresponding to newly formed ${ }^{14} \mathrm{C}$-acetylcholine only, was counted using a scintillation counter. Appropriate controls were performed to verify that ChAT activity was specific (Raynaud et al., 1987).

Immunocytochemistry. Primary antibodies used were mouse monoclonal antibody against $68 \mathrm{kDa}$ neurofilament protein (diluted 1:400) from Sigma; rabbit anti-chicken ChAT (diluted 1:500), a generous gift from Dr. M. Epstein, University of Wisconsin; anti-SCl monoclonal supernatant antibody (diluted 1:5), a generous gift from Dr. C. E. Henderson; and anti-bovine glial fibrillary protein (GFAP) monoclonal antibody (diluted 1:200) from Sigma.

For immunodetection of neurofilament protein, ChAT, and GFAP, the following protocol was carried out. MTNs were cultured on polyDL-ornithine/laminin-coated glass coverslips in 24-well culture dishes (Nunc), and at appropriate times they were rinsed with PBS and fixed with cold 4\% paraformaldehyde in PBS buffer for $10 \mathrm{~min}$, rinsed three times with PBS containing $0.1 \%$ Triton X-100 (PBS-T), and incubated for $30 \mathrm{~min}$ in PBS-T plus 3\% (w/v) BSA. Primary antibodies were used at appropriate concentrations and were left overnight on coverslips at $4^{\circ} \mathrm{C}$. Cultures were washed three times in PBS-T and incubated with fluorescein-conjugated sheep anti-mouse IgG antibody (diluted 1:40) (Boehringer-Mannheim) and/or rhodamine-conjugated goat anti-rabbit IgG antibody (diluted 1:40) (Sigma). Coverslips were mounted with Fluoprep (Biomerieux, Marcy l'Etoile, France) and preparations were observed using an vertical microscope equipped with epifluorescence optics for fuorescein and rhodamine.

For SC-1 immunodetection the following modifications of the general protocol were made. MTNs were cultured for $48 \mathrm{hr}$ as above and, at that time, roughly the $70 \%$ of the culture media was replaced by cold $\left(-20^{\circ} \mathrm{C}\right)$ acetone. After $5 \mathrm{~min}$, cells were rinsed three times with PBS and were incubated for $1 \mathrm{hr}$ at $37^{\circ} \mathrm{C}$ with the SC-1 antibody. Bound antibody was detected with the Vectastain $\mathrm{ABC}$ kit from Vector Laboratories (Burlingame, $\mathrm{CA}$ ) following the manufacturer's instructions.

Electron microscopy. Neurons were plated and cultured as for immunocytochemistry studies. After MTN were cultured for $2 \mathrm{~d}$ in the presence of a saturating concentration of MEX, media were changed, and half of cultures were depleted of MEX. After further $48 \mathrm{hr}$ period, cultures were rinsed twice with cold PBS and fixed for $4 \mathrm{hr}$ in $2.5 \%$ glutaraldehyde in $100 \mathrm{~mm}$ phosphate buffer $\mathrm{pH}$ 7.4. Cultures were next postfixed in buffered $\mathrm{OsO}_{4}$, dehydrated in graded acetone, and flat- embedded in Araldite resin (Fluka, Buchs, Switzerland). Coverslips were detached from Araldite resin by immersion in liquid $\mathrm{N}_{2}$. Thin sections were cut parallel to the surface of culture and stained with lead citrate and uranyl acetate. Sections were examined in a Zeiss EM10 electron microscope.

Inhibition of protein synthesis assay. To assess the efficiency of protein synthesis inhibition, the incorporation of trans-35S-label (a ${ }^{35} \mathrm{~S}$-labeled Met and Cys mixture from ICN-Flow, Bucks, UK) into trichloroacetic acid (TCA)-insoluble protein was measured according to the method of DiStefano et al. (1985). Briefly, neurons were cultured at a density of 30,000 MTNs/well in 24-well tissue culture plates (Nunc). MTNs had grown for $48 \mathrm{hr}$ in basal medium supplemented with $300 \mu \mathrm{g} / \mathrm{ml} \mathrm{MEX}$, media were changed, and cycloheximide (CHX) was added at appropriate doses. At the same time, $25 \mu \mathrm{Ci}$ of trans ${ }^{-35} \mathrm{~S}$-label was added to each well. Media were removed after $15 \mathrm{hr}$, wells were washed once with ice-cold PBS, and $200 \mu \mathrm{l}$ of $0.4 \mathrm{M} \mathrm{NaOH}$ was added to each well. One hour later $100 \mu \mathrm{l}$ was blotted onto Whatman 1 paper. The filters were boiled in $10 \%$ TCA, washed with cold TCA and ethanol, and finally dried. The number of $\mathrm{cpm}$ was determined by scintillation counting. Counts were corrected for nonspecific binding by subtracting the counts bound to culture wells without neurons. To assess the efficiency of transcription inhibitors, the same approach was used except that appropriate drugs were added $6 \mathrm{hr}$ prior to addition of trans $-{ }^{35} \mathrm{~S}-\mathrm{label}$.

Detection of DNA ladder by Southern blotting techniques. MTNs (5 $\times 10^{5} /$ condition) were grown in $35 \mathrm{~mm}$ culture dishes. After $48 \mathrm{hr}$ of culture, neurons were rinsed twice with PBS and detached with $2 \mathrm{ml}$ of cold PBS. MTNs were pelleted by centrifugation at $400 \times \mathrm{g}$ for $4 \mathrm{~min}$ at $4^{\circ} \mathrm{C}$, and resuspended in $500 \mu \mathrm{l}$ of extraction buffer $(100 \mathrm{~mm} \mathrm{NaCl}$, $25 \mathrm{~mm}$ EDTA, $0.5 \% \mathrm{SDS}$ in $10 \mathrm{~mm}$ Tris/ $\mathrm{HCl} \mathrm{pH} 8.0$ ) containing 0.12 $\mathrm{mg} / \mathrm{ml}$ proteinase $\mathrm{K}$ (Boehringer-Mannheim) and $10 \mu \mathrm{g} / \mathrm{ml}$ DNase-free RNase (Sigma). Digestion was performed at $50^{\circ} \mathrm{C}$ for $60 \mathrm{~min}$ and DNA was isolated with the Magic DNA Clean-Up System (Promega) according to the manufacturer's instructions. DNA samples were electrophoresed in a $2 \%$ agarose gel and blotted onto nylon membranes (Boehringer-Mannheim). Blots were probed with total DNA from liver chick isolated with the same protocol except that the Magic DNA Clean-Up System step was substituted by a phenol-chloroform extraction, followed by ethanol precipitation. Probe labeling, hybridization, and detection were carried out using the digoxigenin nucleic acid labeling and detection kit from Boehringer-Mannheim following the manufacturer's instructions.

\section{Results}

\section{Purification process, evaluation of purity, and culture} procedures

The purification procedure was essentially as described by Arakawa et al. (1990) with the minor modifications stated in Materials and Methods. MTNs were purified on the basis of their buoyant densities using metrizamide gradients. This procedure yielded pure $(>90 \%)$ cultures of MTNs as may be inferred from the following criteria. (1) As shown in Figure 1, cells dissociated from spinal cords looked very heterogeneous in size (mean diameter $\pm \mathrm{SD}, 9.00 \pm 2.01 \mu \mathrm{m}$; range, $4.84-20.13 \mu \mathrm{m} ; n=688)$ (Fig. $1 A$ ) and brightness under phase-contrast optics (Fig. 1D). After metrizamide purification, cells in the intermediate layer were found to be more homogeneous (Fig. $1 E$ ) and have larger diameters (mean diameter $\pm \mathrm{SD}, 13.13 \pm 2.19 \mu \mathrm{m}$ : range, 9.18$19.35 \mu \mathrm{m} ; n=132$ ) (Fig. $1 B$ ) whereas cells in the pellet remained heterogeneous (Fig. $1 F$ ) and smaller (mean diameter $\pm \mathrm{SD}, 8.23$ $\pm 1.59 \mu \mathrm{m}$; range, 5.34-13.80 $\mu \mathrm{m} ; n=233$ ) (Fig. 1C). (2) In agreement with reports from other laboratories (Martinou et al., 1989; Arakawa et al., 1990; Jeong et al., 1991), we were able to label MTNs retrogradely by injecting DiI in muscle tissuc of chick embryos $12 \mathrm{hr}$ prior to purification. We found that $2.3 \%$ of the cells were labeled in the initial spinal cord dissociate whereas this percentage increased to $6.1 \%$ in the metrizamide interphase (data not shown). (3) The specific ChAT activity (expressed as $\mathrm{cpm} / 10^{6}$ cells $\times$ minutes of reaction) in the in- 

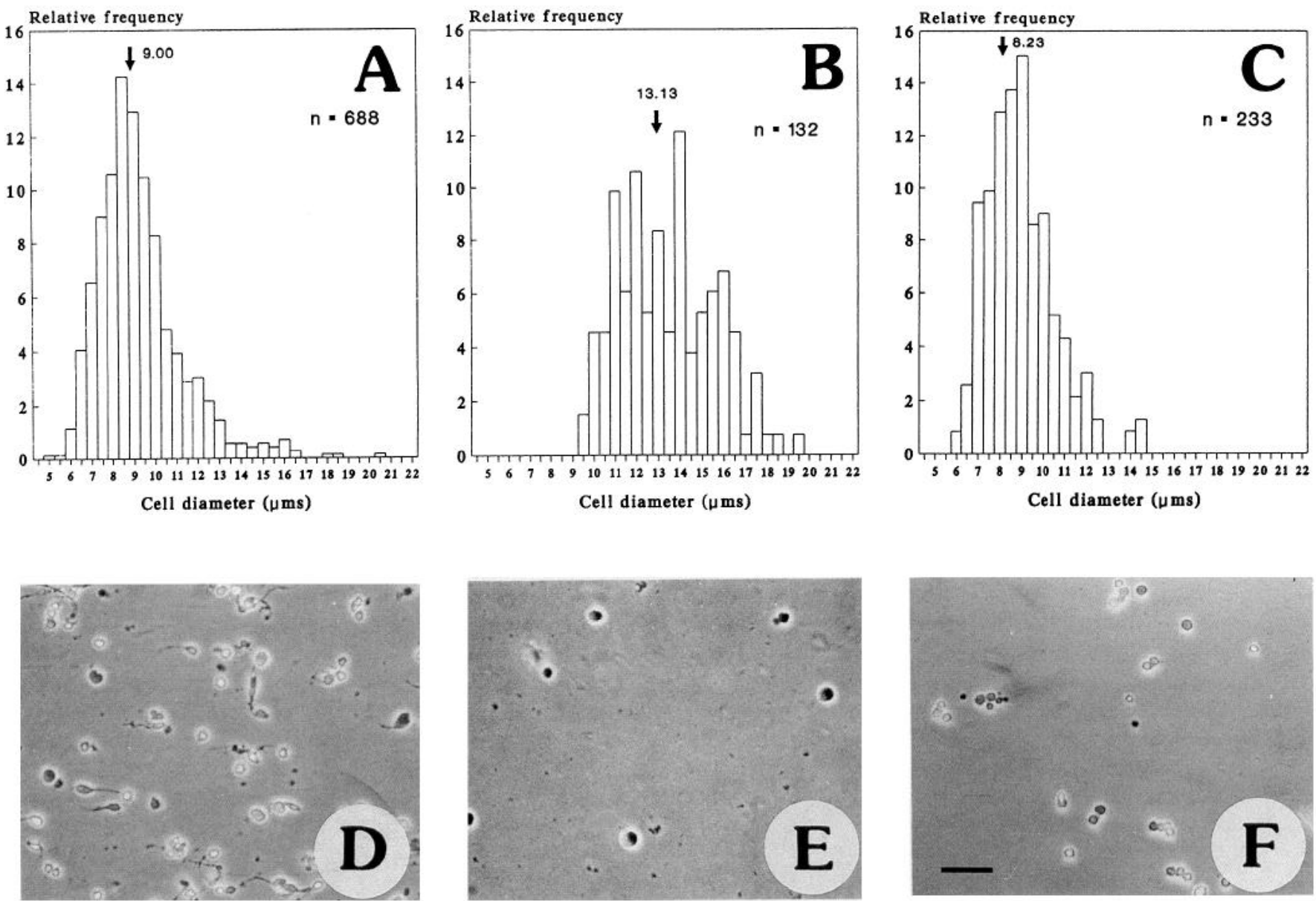

Figure 1. Metrizamide gradient purification yields a homogeneous population of cells: size distribution $(A-C)$ and morphological appearance under phase contrast optics $(D-F)$ of whole dissociated spinal cords $(A, D)$, and of cells remaining in the interphase $(B, E)$ or in the pellet $(C, F)$ of the metrizamide gradient. Arrows in $A-C$ indicate mean value. Scale bar, $50 \mu \mathrm{m}(D-F)$.

termediate layer cells $(542 \pm 30.4)$, was found to be largely enriched with respect to either unfractionated cells $(272 \pm 36.7)$ or cells remaining in the pellet after metrizamide gradient centrifugation (61.9 \pm 14 ) (Fig. 2). (4) Double staining of cultures with monoclonal antibody against the $68 \mathrm{kDa}$ neurofilament (Fig. $3 A$ ) protein and polyclonal antiserum against ChAT protein (Fig. $3 B$ ) showed staining by both antibodies of $>95 \%$ of cells in the wells. The staining was present in cell bodies and neurites. No cells showed positive staining for GFAP. This result correlates with the absence of proliferating cells observed in culture wells even after long times of culture (up to $14 \mathrm{~d}$ ). (5) Cultures stained with a monoclonal antibody against SC1 antigen showed that more than $90 \%$ cells were immunoreactive after $2 \mathrm{~d}$ in culture. $\mathrm{SC} 1$ is a surface marker specific for MTNs, dorsal root ganglion neurons, and floor plate cells of the chick embryo (Tanaka and Obata, 1984). The protocol was established after a report describing that $\mathrm{SCl}$ antigens are sensitive to trypsinization and reappear after $36 \mathrm{hr}$ of culture in vitro (BlochGallego et al., 1991). Immunoreactive neurons were not floor plate cells since these cells have a characteristic fibroblast-like morphology.

Taken together, these criteria demonstrate that metrizamide gradient purification yields highly purified MTNs ( $>90 \%)$ from spinal cord of E5.5 chick embryos.

As it has been previously described by several laboratories,

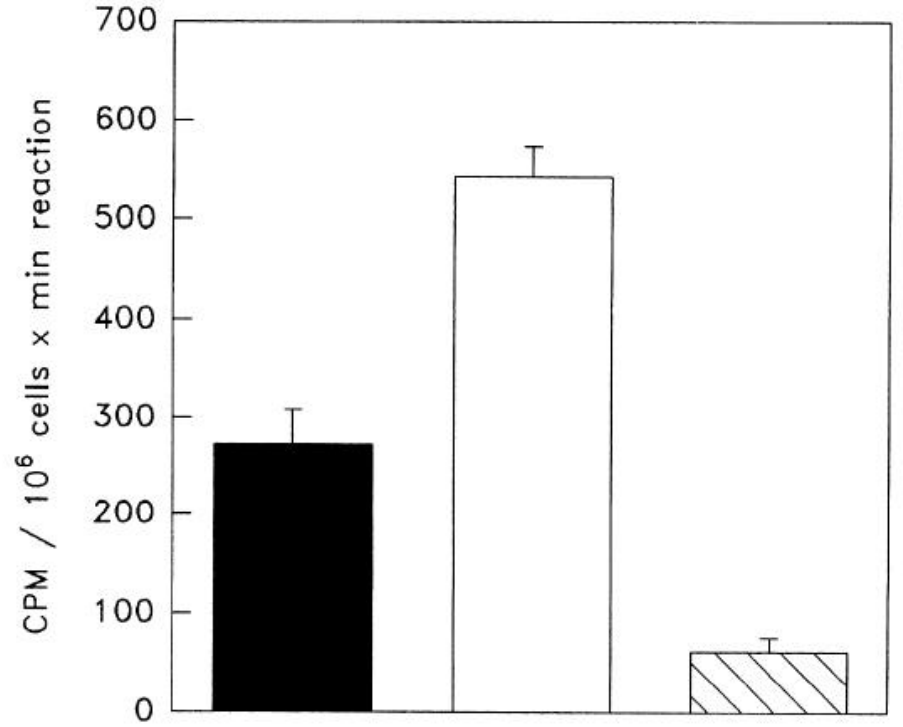

Figure 2. Neurons isolated with the metrizamide gradient technique are highly enriched for ChAT activity. Solid bar, ChAT activity in whole spinal cord dissociates; open bar, ChAT activity in the cells of the metrizamide interphase; hatched bar, ChAT activity in the cells in the pellet. The quantification was performed on six different MTN purifications and measures were performed in triplicate. For SEM only the number of different experiments $(n=6)$ was taken into consideration. 

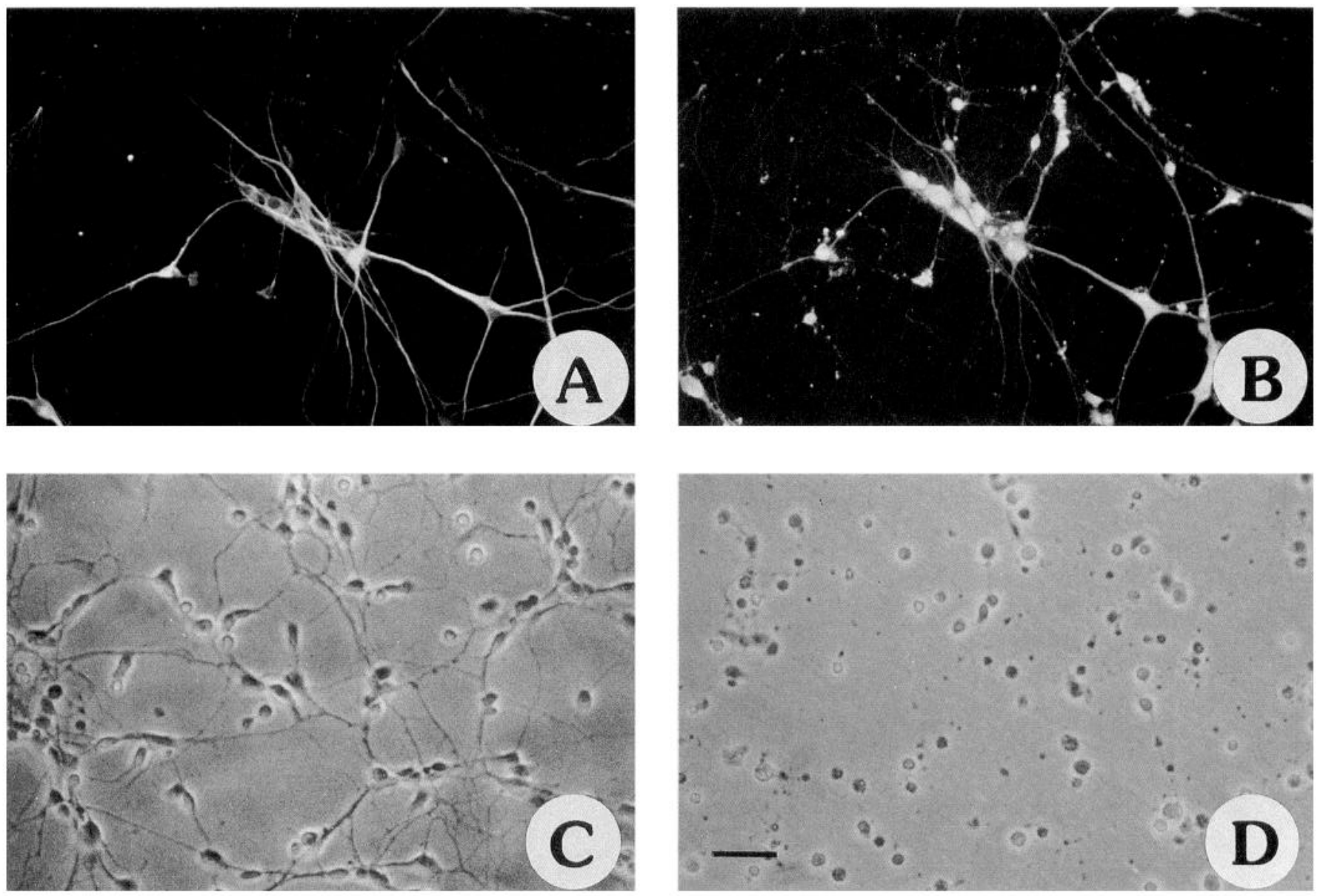

Figure 3. Morphological features of cultured MTNs isolated with the metrizamide gradient technique. $A$ and $B$, MTNs cultured for $7 \mathrm{~d}$ in the presence of $300 \mu \mathrm{g} / \mathrm{ml}$ MEX: double immunostaining with antibodies against the $68 \mathrm{kDa}$ neurofilament protein $(A)$ and against ChAT enzyme $(B)$. Note that all cells in the picture are labeled by both antibodies. $C$, MTNs cultured for $2 \mathrm{~d}$ in the presence of $300 \mu \mathrm{g} / \mathrm{ml} \mathrm{MEX.} D$, MTNs cultured for $2 \mathrm{~d}$ without MEX. Scale bar, $50 \mu \mathrm{m}(A-D)$.

MTNs are strictly dependent on muscle extract for survival (Fig. $3 C, D$ ). Purified MTNs cultured in $\mathrm{L} 15 \mathrm{H}$ medium without MEX died within $2-3 \mathrm{~d}$ (Fig. $3 D$ ), and $<5 \%$ of the neurons initially plated survived after 1 week. These neurons initially grew short processes that rapidly became fragmented and they finally detached from the culture dish. MTNs died during the first $36 \mathrm{hr}$ in culture in percentages up to $40 \%$ even when saturating concentrations of MEX $(>300 \mu \mathrm{g} / \mathrm{ml})$ were included in the culture medium. Thereafter, the number of MTNs in the culture stabilized. Living neurons extended long processes that showed positive staining for $68 \mathrm{kDa}$ neurofilament protein (Fig. $3 A$ ) as well as for ChAT (Fig. 3B), indicating their neuronal cholinergic nature. MEX had no toxic effects even at high concentrations $(500 \mu \mathrm{g} / \mathrm{ml})$ and the half-maximal effective survival promoting concentration was found to be $75 \mu \mathrm{g} / \mathrm{ml}$ for P10D5 extract. MTNs were usually cultured at saturating concentrations of MEX $(300 \mu \mathrm{g} / \mathrm{ml})$ for $2 \mathrm{~d}$ (to allow damaged neurons to die) and then culture media were replaced with media to be assayed. After MEX deprivation, neurons began to die and $>70 \%$ of the neurons degenerated after $48 \mathrm{hr}$. In contrast, at that time, $>90 \%$ of the neurons were alive in sister cultures that were continuously cultured in the presence of MEX. In long-term cultures MEX was not able to support survival of MTNs any longer (the survival after $7 \mathrm{~d}$ in the presence of MEX was $\sim 20 \%$; data not shown), albeit culture medium was replaced every $2 \mathrm{~d}$.

Experiments were performed with the Hoechst 33258 dye in order to quantify the percentage of apoptotic MTNs after MEX deprivation. This dye specifically binds to the double-stranded DNA and emits at $490-500 \mathrm{~nm}$ when excited at $360 \mathrm{~nm}$. Apoptotic cells display a highly condensed DNA that is normally fragmented in two or more chromatin aggregates (Fig. $4 G$ ). In cultures of MTNs grown continuously in the presence of MEX the percentage of cells that display this morphology was found to be $2.15 \pm 0.15 \%$ of the neurons. However, after MEX de-

Figure 4. Ultrastructural morphology of MTN cell death upon trophic deprivation in vitro partially resembles that occurring naturally in vivo. A, MTNs in the lumbar lateral motor column of an E8 chick embryo. B, Neurons of the metrizamide interphase cultured for $2 \mathrm{~d}$ in the presence of MEX. $C$, MTNs in the lumbar lateral motor column of an E8 chick embryo dying during the physiological cell death period. $D-G, C u l t u r e d$ neurons of the metrizamide interphase dying after $2 \mathrm{~d}$ of MEX deprivation. In $E$ there are dying neurons with a high number of lipid droplets in their cytoplasm. $G$, Chromatin staining with Hoechst 33258 dye of a MTN culture after $2 \mathrm{~d}$ of MEX deprivation. Note the two dying MTNs displaying typical signs of condensed and fragmented DNA (arrows). Scale bars: $A$ and $B, 5 \mu \mathrm{m} ; C-E, 1 \mu \mathrm{m} ; F, 2.5 \mu \mathrm{m} ; G, 25 \mu \mathrm{m}$. 

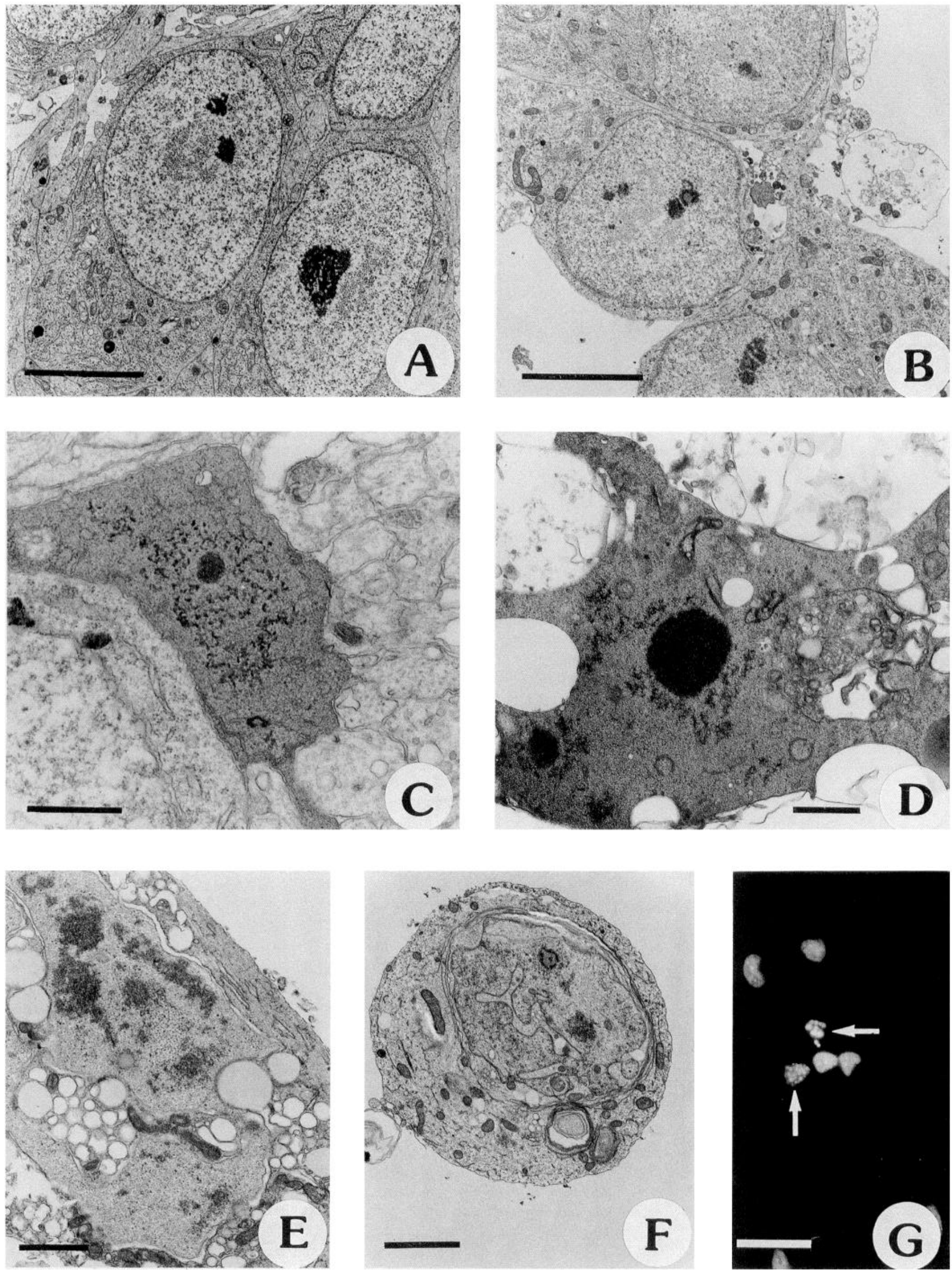
Table 1. Inhibitors of protein synthesis suppress the death of MTNs that occurs after muscle extract deprivation

\begin{tabular}{lcl} 
& \multicolumn{2}{l}{ Survival } \\
\cline { 2 - 3 } & $24 \mathrm{hr}$ & $48 \mathrm{hr}$ \\
\hline With MEX $(300 \mu \mathrm{g} / \mathrm{ml})$ & $105.4 \pm 17.7$ & $87.6 \pm 7.6$ \\
Without MEX & $53.3 \pm 7.3$ & $37.0 \pm 5.6$ \\
Without MEX + cycloheximide & & \\
$\quad(0.5 \mu \mathrm{g} / \mathrm{ml})$ & $105.0 \pm 8.7$ & $93.8 \pm 9.7$ \\
Without MEX + anysomycin $(100 \mu \mathrm{M})$ & $79.9 \pm 12.9$ & $72.1 \pm 2.8$ \\
Without MEX + puromycin $(200 \mu \mathrm{M})$ & $95.0 \pm 13.5$ & $33.4 \pm 1.3$
\end{tabular}

Cultures were grown for $48 \mathrm{hr}$ in the prescnce of $300 \mu \mathrm{g} / \mathrm{ml} \mathrm{MEX.} \mathrm{They} \mathrm{werc} \mathrm{next}$ deprived of MEX, and MEX, drugs, or none was added to the cultures as appropriate. Survival was evaluated 24 and $48 \mathrm{hr}$ later. Values are means \pm SEM of cell survival at indicated times from a single experiment that was repeated twice more with results comparable to those presented. $n=6$ for all groups.

privation this percentage increased considerably. After $12 \mathrm{hr}$ of MEX deprivation we found that $5.03 \pm 0.6 \%$ of the cells displayed apoptotic nuclei whereas this percentage was found to be $3.92 \pm 0.53 \%$ at $24 \mathrm{hr}$ and $3.2 \pm 0.2 \%$ at $48 \mathrm{hr}$ of MEX deprivation. $\mathrm{CHX}$ at $0.5 \mu \mathrm{g} / \mathrm{ml}$ was able to prevent the increase in the percentage of apoptotic nuclei after MEX deprivation.

\section{Ultrastructural analysis of MTN cell death in vitro}

Morphology of neurons purified with the metrizamide gradient technique and grown in the presence of MEX for $48 \mathrm{hr}$, resembled that of MTNs found in the lateral motor column of E8E10 chick embryos (Fig. 4A,B). They showed a large nucleus containing finely dispersed chromatin and one or two nucleoli. Their cytoplasm contained large quantities of free polyribosomes, a moderately developed rough endoplasmic reticulum, and abundant mitochondria. Golgi complexes were highly prominent and were sometimes found surrounding a centriole. Tubulovesicular structures were observed throughout the entire cytoplasm, becoming more conspicuous in the vicinity of Golgi regions. A cytoskeletal network composed of microtubules and filaments was dispersed in the neuronal cytoplasm, even though it also formed densely packed bundles. Many neurites emerged from the cell bodies and formed a network that occupied the space between the neuronal somas. Neurites contained a prominent cytoskeleton, membrane-bound vesicles and tubules, and some mitochondria. Neurites growing along the surface of cell bodies were a common finding. Also, spherical neurite endings frequently established synaptic-like contacts focally distributed on the surface of cell bodies.

This overall picture changed substantially in MEX-deprived MTN cultures. Although some neurons looked healthy even after $48 \mathrm{hr}$ of MEX deprivation, many cells exhibited various degrees of ultrastructural abnormality (Fig. $4 E, F$ ). Some neurons had a rounded profile and contained a highly convoluted nucleus (Fig. $4 F$ ) with a wide range of chromatin condensation. Their cytoplasm contained lipid droplets (Fig. 4E), membranebound vacuoles, and cytoskeletal filaments and exhibited no signs of organelle degeneration. Some other neurons displayed extreme cytoplasmic condensation in association with disruption of the nuclear envelope and dispersion of chromatin throughout the cytoplasm. The chromatin was highly condensed and formed thread-like structures and round compact masses (Fig. 4D). Cytoplasmic organelles such as mitochondria could be seen without gross structural alterations. However, structures resembling autophagic vacuoles that contained degenerating mi-
Table 2. Inhibitors of mRNA synthesis or processing suppress the death of MTNs that occurs after muscle extract deprivation

\begin{tabular}{lll} 
& \multicolumn{2}{l}{ Survival } \\
\cline { 2 - 3 } & $24 \mathrm{hr}$ & $48 \mathrm{hr}$ \\
\hline With MEX $(300 \mu \mathrm{g} / \mathrm{ml})$ & $93.1 \pm 5.1$ & $95.7 \pm 5.4$ \\
Without MEX & $55.0 \pm 4.9$ & $12.3 \pm 3.0$ \\
Without MEX + actinomycin D & & \\
$\quad(10 \mu \mathrm{g} / \mathrm{ml})$ & $76.3 \pm 5.0$ & $9.9 \pm 2.2$ \\
Without MEX + camptothecin $(100 \mathrm{nM})$ & $85.8 \pm 6.9$ & $77.4 \pm 8.2$ \\
Without MEX + cordycepin $(25 \mu \mathrm{M})$ & $74.9 \pm 7.0$ & $69.6 \pm 4.7$
\end{tabular}

Cultures werc grown for $48 \mathrm{hr}$ in the presence of $300 \mu \mathrm{g} / \mathrm{ml}$ MEX. They were then deprived of MEX, and MEX, drugs, or none was added to the cultures as appropriate. Survival was evaluated 24 and $48 \mathrm{hr}$ later. Values are means \pm SEM of cell survival at indicated times from a single experiment that was repeated twice more with results comparable to those presented. $n=6$ for all groups.

tochondria and concentric membrane lamellar bodies were also occasionally observed in these cells (Fig. 4D).

Neurites of MTNs deprived of MEX showed a broad spectrum of degenerative changes. Most of them were severely swollen, had an electron-lucid appearance, and were fragmented into dilated spherical structures that contained degenerating mitochondria, large dense granules, small vesicles, and scattered amorphous material (Fig. $4 G$ ). Other neurites were retracted, had a dark appearance, and contained condensed amorphous granular material. Pericellular synaptic-like endings on degenerating neurons appeared extremely swollen and with evident signs of structural disruption of their content.

\section{Blocking lysosomal function does not prevent MTN cell death}

Martin et al. (1988) have reported that lysosomal function is not involved in the death of sympathetic neurons after trophic deprivation. We have assayed various inhibitors of lysosomal proteases in order to analyze the same process in MTN cell death after MEX deprivation. PMSF, chloroquine, and leupeptin at doses from $1 \mu \mathrm{M}$ to $1 \mathrm{mM}$ were added to cultures of MTNs that had been deprived of trophic factor after $48 \mathrm{hr}$ of culture. The survival found $48 \mathrm{hr}$ later was similar to that of cultures without protease inhibitors.

\section{$M T N$ death after trophic deprivation is an active process}

The process of neuronal death after trophic deprivation has been shown to require de novo synthesis of mRNA and proteins in vitro (Martin et al., 1988; Scott and Davies, 1990; Edwards et al., 1991). In order to know whether or not the same is true for MTNs dying as a consequence of deprivation of MEX, cultures were treated with inhibitors of either transcription or translation (Tables 1, 2). For this purpose three different drugs that block protein synthesis (CHX, anysomycin, and puromycin) and three different drugs that block mRNA synthesis or processing [actinomycin D (ActD), camptothecin (CAMP), and cordycepin (CORD)] were used. MTNs were fed for $48 \mathrm{hr}$ with MEX, and media were then replaced with basal medium without MEX but containing transcription or translation blockers. The efficiency of CHX in decreasing protein synthesis was assessed by determining its ability to block the incorporation of ${ }^{35} \mathrm{~S}$-labeled amino acids into TCA-precipitable proteins.

As reported in Table 1, we found that $\mathrm{CHX}$ efficiently blocked neuronal death that occurs after deprivation of MEX in vitro. The effect was half-maximal at $0.05 \mu \mathrm{g} / \mathrm{ml}(\sim 175 \mathrm{nM})$ and complete at $0.5 \mu \mathrm{g} / \mathrm{ml}(\sim 1.75 \mu \mathrm{M})$. Doses greater than $5 \mu \mathrm{g} / \mathrm{ml}$ were 
found to be toxic for MTNs. CHX blocked incorporation of ${ }^{35} \mathrm{~S}$ labeled amino acids into TCA-precipitable proteins by $\sim 50 \%$ when used at $0.05 \mu \mathrm{g} / \mathrm{ml}$ and, at $0.5 \mu \mathrm{g} / \mathrm{ml}$, the inhibition was almost complete $(-90 \%)$. Neurites of MTNs treated with CHX became progressively thinner but were continuous and fragmentation did not occur. Degeneration of cell bodies was not observed, although they became progressively smaller. When CHX $(0.5 \mu \mathrm{g} / \mathrm{ml})$ was added to the culture medium at the time of seeding MTNs remained bright, attached to the culture substrata and had a healthy appearance even without MEX. However, no neurites extended from the cell bodies, which may be the consequence of the high efficiency of protein synthesis blockade. We have found CHX not to be toxic for MTNs cultured with or without MEX until after $4 \mathrm{~d}$ of treatment. At that time, MTNs began to fragmentate and detach from the culture dish surface.

Similar results to those obtained with $\mathrm{CHX}$ were also observed with other protein synthesis blockers in the same set of experiments (see Table 1 for survival percentages). Anisomycin was able to prevent MTN death in the range of 50-200 $\mu \mathrm{M}$ but concentrations higher than $200 \mu \mathrm{M}$ were toxic. We found that $100 \mu \mathrm{M}$ was the most effective dose. Puromycin was also effective in preventing MTN death after deprivation of MEX. We found the optimal dose to be $200 \mu \mathrm{M}$ but, at longer times of culture $(48 \mathrm{hr})$, puromycin was less effective.

In another series of experiments we sought to examine whether or not the inhibition of cell death after blockade of protein synthesis was, in turn, dependent on transcription of new molecules of mRNA. For this purpose we examined in MTNs deprived of MEX the effect of several drugs that interfere with transcription or processing of mRNA. As reported in Table 2, we found that ActD, at doses ranging from 0.5 to $10 \mu \mathrm{g} / \mathrm{ml}$, was able to rescue MTNs from death resulting from deprivation of MEX. The most effective dose was $10 \mu \mathrm{g} / \mathrm{ml}$. However, ActD proved to be highly toxic for MTNs in longer times of culture $(48 \mathrm{hr})$. This toxic effect of ActD was found even when the drug was added to cultures containing MEX (data not shown).

Other drugs that alter mRNA transcription or processing (CAMP and CORD) also protected MTNs from cell death after deprivation of MEX (Table 2). CAMP was effective in the range of doses from $50 \mathrm{~nm}$ to $1 \mu \mathrm{M}$, with $100 \mathrm{~nm}$ being the most effective. Doses greater than $5 \mu \mathrm{M}$ proved to be toxic for MTNs. Similar results were found for CORD (effective range of doses, 5-100 $\mu \mathrm{M}$; most effective dose, $25 \mu \mathrm{M})$. CAMP was found to be less toxic for MTNs than ActD (data not shown). However, all of the drugs tested that block mRNA synthesis or processing were found to be more toxic than $\mathrm{CHX}$ at longer times of culture (48 hr).

The degree of transcription inhibition caused by the above mentioned drugs was estimated by measuring the incorporation of ${ }^{35} \mathrm{~S}$-labeled amino acids into TCA-precipitable protein. Results were expressed as the percentage of radioactivity incorporated by sister cultures that did not receive the drug. When either ActD or CAMP was added to the cultures $6 \mathrm{hr}$ prior to the ${ }^{35}$ S-labeled amino acid mixture, we found an inhibitory effect on the incorporation of TCA-precipitable radioactivity greater than $90 \%$.

Laddering pattern of DNA degradation occurs in MTNs dying after trophic deprivation

A hallmark of programmed cell death or apoptosis is the DNA degradation into oligonucleosomal-sized fragments subsequent

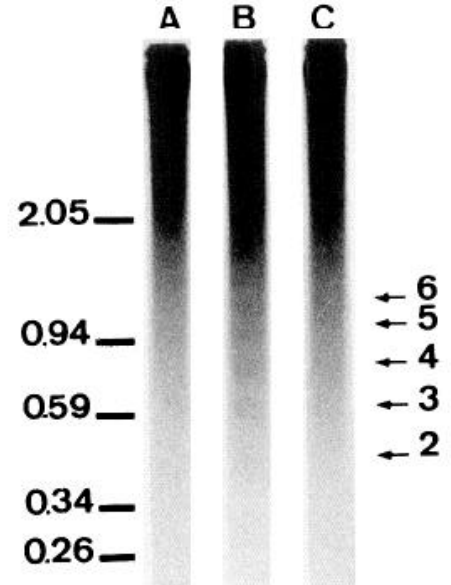

Figure 5. Ladder pattern of DNA degradation occurring in MTNs deprived of MEX in vitro: DNA from MTNs cultured in the presence of $\operatorname{MEX}(A)$, and from MEX-deprived MTNs cultured without $(B)$ or with $(C)$ CHX $(0.5 \mu \mathrm{g} / \mathrm{ml})$. DNA was extracted from 2-d-old cultures. To the right, arrows indicate the position and number of oligonucleosomal-sized DNA degradation bands. Molecular weight references are shown to the left and are expressed in kilobase pairs.

to activation of a $\mathrm{Ca}^{2+} / \mathrm{Mg}^{2+}$-dependent endonuclease (Arends et al., 1990). Analysis of endonuclease-fragmented DNA by agarose gel electrophoresis yielded a typical banding pattern. This pattern is usually referred to as ladder pattern of DNA degradation. We were unable to detect DNA laddering after MTN deprivation of MEX when DNA was analyzed in agarose gels stained with ethidium bromide (data not shown). This was probably due to the relatively low number of MTNs $\left(5 \times 10^{5}\right)$ used for this analysis, which was limited by the number of MTNs that can be purified with the metrizamide gradient technique. Therefore, we used a similar approach to that described by Edwards et al. (1991). This procedure takes advantage of the high sensitivity of Southern blotting techniques, using digoxigenin-labeled chicken genomic DNA as a probe. Figure 5 shows, in lane A, DNA corresponding to MTNs grown in the presence of MEX. Lane B shows a pattern of laddering due to DNA fragmentation subsequent to MTN cell death after deprivation of MEX. Lane C corresponds to MTNs grown without MEX plus $0.5 \mu \mathrm{g} / \mathrm{ml} \mathrm{CHX}$, which was previously shown to prevent MTN death. It is clear that inhibition of protein synthesis also prevented DNA degradation.

\section{Commitment to death in muscle extract-deprived MTNs}

As can be inferred from the previous results, MTN cell death after MEX deprivation features the major characteristics of apoptosis. Therefore, we next decided to determine in detail the kinetics of this process. A previous report (Edwards et al., 1991) argues that NGF can rescue sympathetic neurons at later stages of the death process than blockers of protein or RNA synthesis. These results were explained on the grounds that NGF would be able to modify posttranslationally the putative killer proteins synthesized by trophic factor-deprived sympathetic neurons. However, Martin et al. (1992) have reported that, when neurons lose their potentiality to be rescued from death by blocking protein or RNA synthesis, they also lose the potentiality to be rescued by their specific trophic factor, that is, NGF.

Taking into account these apparently contradictory results, we sought to investigate the process of commitment to cell death 

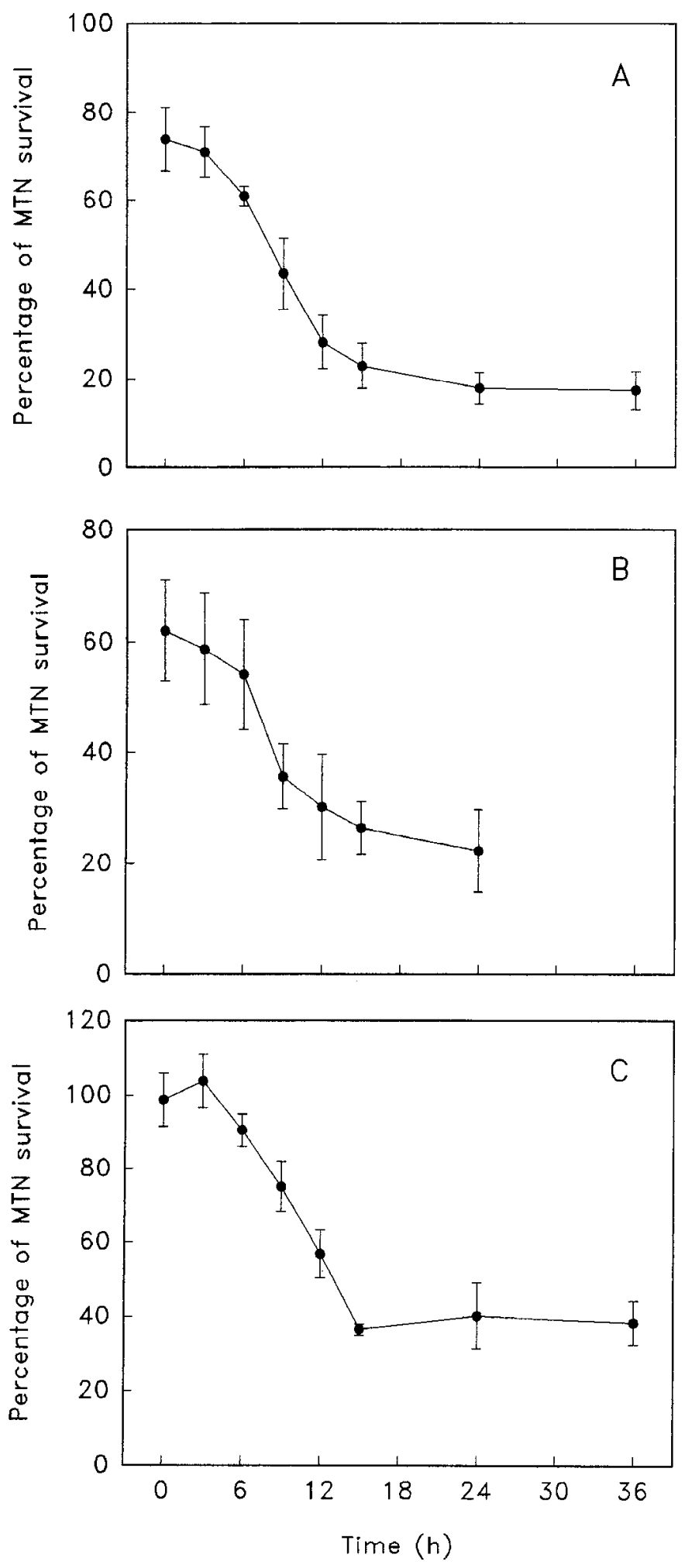

Figure 6. Commitment of MTNs to cell death upon MEX trophic deprivation in vitro. MTNs were cultured for $48 \mathrm{hr}$ in the presence of a saturating concentration $(300 \mu \mathrm{g} / \mathrm{ml})$ of $\mathrm{MEX}$, were then deprived, and at regular intervals (up to $36 \mathrm{hr})$, MEX $(300 \mu \mathrm{g} / \mathrm{ml} ; A)$, ActD (10 $\mu \mathrm{g} / \mathrm{m} ; B)$, or CHX $(0.5 \mu \mathrm{g} / \mathrm{ml} ; C)$ was added to the cultures. Survival was evaluated $48 \mathrm{hr}(A, C)$ or $36 \mathrm{hr}(B)$ after addition of MEX or drugs. Time $0 \mathrm{hr}$ for all graphs represents the number of MTNs that were continuously cultured in the presence of MEX. The last point on the graphs (time $36 \mathrm{hr}$ for $A$ and $C$, and time $24 \mathrm{hr}$ for $B$ ) was the percentage in another population of neuronal cells, that is, MTNs, which do not depend on NGF to survive but depend on trophic activities contained in MEX (Arakawa et al., 1990). Using our culture system we first looked for the existence of a commitment point to cell death in MTNs deprived of MEX.

For this purpose, MTNs were cultured for $48 \mathrm{hr}$ in the presence of MEX. At that time, they were deprived of MEX and the number of MTNs was scored in the central area of the culture wells. At regular intervals of deprivation (up to $36 \mathrm{hr}$ ), MEX was added back to subsets of MTNs. Survival was evaluated as described in Materials and Methods.

Figure $6 A$ shows an experiment in which $74.0 \pm 7.2 \%$ of the MTNs that had continuously grown in the presence of MEX survived. However, only $17.5 \pm 4.3 \%$ of the MTNs initially counted survived when they were never returned to a trophic environment. The commitment point was found to be $\sim 10 \mathrm{hr}$, since at this time, MEX could only prevent the death of half of the deprived MTNs. After $\sim 15 \mathrm{hr}$, MEX was no longer able to rescue any more MTNs from cell death. This experiment was repeated twice more with nearly identical results.

We sought further to determine how much time MTNs without MEX need to synthesize the products that induce their own death. Thus, we investigated how long after deprivation of MEX the addition of ActD or CHX could be delayed and still prevent neuronal death. For these experiments, MTNs were deprived after being in the presence of MEX for $48 \mathrm{hr}$. Cultures received $\mathrm{CHX}$ at various times after deprivation (up to $36 \mathrm{hr}$ ) and survival was evaluated $36 \mathrm{hr}$ later. Experiments using ActD were limited to $24 \mathrm{hr}$ due to the high toxicity of this drug.

As can be seen in Fig. $6 C$, during the first $6 \mathrm{hr}$ of MEX deprivation, $\mathrm{CHX}$ was able to rescue from cell death $>90 \%$ of the cells that would otherwise die. However, after $15 \mathrm{hr}$ without MEX, CHX failed to rescue any MTNs from cell death. By using this approach, the commitment point was found to be $\sim 10 \mathrm{hr}$. These results correlated fairly well with those of experiments in which readdition of MEX was used to rescue neurons. Similar experiments were performed using ActD instead of CHX. As shown in Figure $6 B$, results obtained with ActD did not differ substantially from those obtained by blocking protein synthesis, featuring a commitment point of $\sim 10 \mathrm{hr}$.

\section{Is the cell death program permanently expressed after trophic deprivation?}

The rationale behind programmed neuronal death after trophic deprivation is the activation of the expression of death genes. It is not known, however, whether this expression is permanent or not. Previous reports from Martin et al. (1988) and Edwards et al. (1991), have shown that NGF was able to rescue NGFdeprived sympathetic neurons maintained alive with $\mathrm{CHX}$ during periods of $48 \mathrm{hr}$ and $72 \mathrm{hr}$. If one assumes that transcription of death genes after trophic deprivation is permanent and $\mathrm{CHX}$ is able to maintain neurons alive for long periods of time by blocking translation of these mRNAs, one would expect that whenever $\mathrm{CHX}$ was withdrawn from the cultures, the death program would proceed forward, thus resulting in the death of neurons. Yet, it would be possible to imagine that even if the death protein mRNAs were translated, NGF would be able to

of survival when MTNs were cultured without MEX and never returned to a MEX-containing culture medium $(A)$ or never received ActD $(B)$ or $\mathrm{CHX}(C)$. 
counter the effects of the death proteins by posttranslational means, as has been suggested by Edwards et al. (1991). However, if this were the case one would expect that the rescuing effect of NGF should occur equally no matter for how long the neurons had undergone trophic factor deprivation and CHX treatment. In order to test this hypothesis, a series of experiments were carried out in which transcription was not directly affected but protein synthesis was hlocked with CHX when MEX was withdrawn. After varying times (up to $48 \mathrm{hr}$ ), CHX was removed from cultures and cells were re-fed with MEX. Survival was evaluated $24 \mathrm{hr}$ and $48 \mathrm{hr}$ later. Figure 7 illustrates the results obtained in one representative experiment using this approach. From 4 hr of MEX deprivation onward, there was a progressive decrease in the percentage of MTNs that could be rescued from cell death, and the lowest values were reached after $12 \mathrm{hr}$. MEX rescued half of the MTNs after $\sim 10 \mathrm{hr}$ of inhibition of protein synthesis. However, when MTNs were cultured without MEX plus $\mathrm{CHX}$ for $24 \mathrm{hr}$ or $48 \mathrm{hr}, \mathrm{CHX}$ was washed out, and MEX was added back to cultures for another $48 \mathrm{hr}$, we found that MTNs did not die; that is, MEX supported the survival of almost all MTNs (Fig. 7). This experiment was repeated six times with comparable results.

\section{Discussion}

In the present article we have characterized the process of MTN death upon deprivation of trophic support. For this purpose, we purified MTNs from E5.5 chick embryos with a metrizamide gradient technique. This technique, first described by Schnaar and Schaffner (1981), was later modified (Dohrmann et al., 1986; Arakawa et al., 1990) and has been extensively used to purify this population of neurons from mouse, rat, and chick embryos (Flanigan et al., 1985; Martinou et al., 1989; Caroni and Grandes, 1990; McManaman et al., 1990; Jeong et al., 1991; Juurlink et al., 1991; Martinou et al., 1992; Hughes et al., 1993). To purify a homogeneous population of neurons from the CNS is a rather complicated task because neurons coexist with other cells either neuronal or glial. The metrizamide gradient MTN purification technique takes advantage of the fact that MTNs at this stage of development (E5.5) behave as a homogeneous population and are the cells with the lowest density in the spinal cord. In order to assess the purity of the population we have used morphological and biochemical criteria. The metrizamide gradient technique yielded in our hands a pure $(>90 \%)$ population of MTNs.

The identification of a "classical" trophic factor synthesized by muscle tissue remains elusive; however, several laboratories have found that unpurified soluble extracts from muscle tissue are able to maintain MTNs alive both in vitro and in vivo (Schnaar and Schaffner, 1981; Dohrmann et al., 1986, 1987; O'Brien and Fishbach, 1986; Oppenheim et al., 1988; McManaman et al., 1990; Bloch-Gallego et al., 1991; Houenou et al., 1991; Juurlink et al., 1991). In our experimental strategy we have used extracts from denervated muscle since denervation increases the total content of trophic activity for MTNs (Henderson et al., 1983; J. X. Comella, C. Sanz-Rodriguez, M. Aldea, and J. E. Esquerda, unpublished observations), probably as a consequence of an increase in the level of mRNA molecules for this elusive trophic factor (Rassendren et al., 1992).

MTNs were cultured for $48 \mathrm{hr}$ in the presence of MEX prior to examining the effects of any drug. This was established after the observation that a sizeable fraction of cells $(\sim 30-40 \%)$ died within the initial $24 \mathrm{hr}$ of culture even when cultured in the

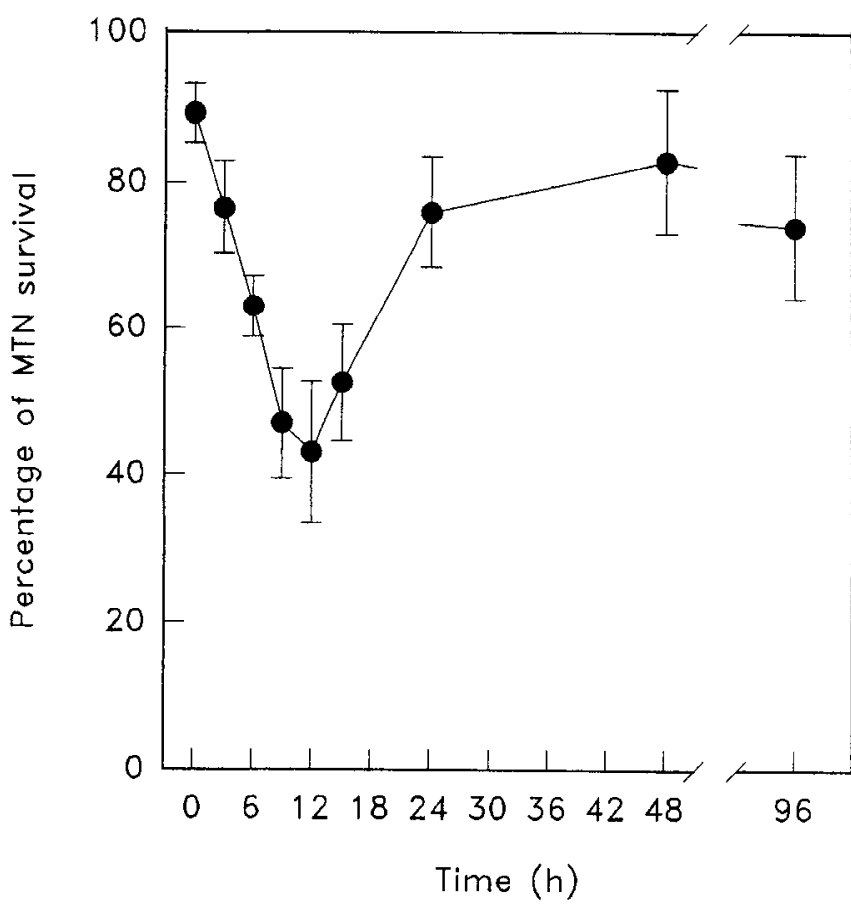

Figure 7. The activation of the cell death program in MTNs upon trophic deprivation in vitro seems to be transient. MTNs were cultured for $48 \mathrm{hr}$ in the presence of a saturating concentration $(300 \mu \mathrm{g} / \mathrm{ml})$ of MEX, were then deprived and maintained alive in the presence of CHX $(0.5 \mu \mathrm{g} / \mathrm{ml})$, and at regular intervals (up to $48 \mathrm{hr}$ ), media were replaced with fresh media containing MEX without $\mathrm{CHX}$. Survival was evaluated $48 \mathrm{hr}$ after readdition of MEX.

presence of saturating concentrations of MEX. Most likely this would be due to the isolation procedure that probably caused irreversible damage to a certain proportion of MTNs. In other procedures used as far to isolate pure populations of neurons (e.g., those in the PNS), the addition of trophic factors (e.g., neurotrophins) at saturating concentrations does not rescue all the neurons initially seeded. In addition, it should be considered that MTNs are very fragile neurons and extreme care must be taken during the isolation process (see Discussion in Arakawa et al., 1991).

MTNs even in the presence of MEX cannot be maintained in culture indefinitely by using MEX as a trophic factor source. MEX kecps ncarly all MTNs healthy until the sixth day in culture (Fig. 3C). Thereafter, the number of MTNs steadily declines and at $9 \mathrm{~d}$ only $20 \%$ of the neurons remain alive. This behavior may indicate a shift in trophic requirements. It is important to keep in mind that supraspinal and muscle afferent projections to lumbosacral MTNs develop fairly late in vivo (after E13) (Oppenheim, 1975; Lee and O'Donovan, 1991) and it is possible that these new inputs add some additional requirements for survival, perhaps through a change in the pattern of electrical stimulation of MTNs. In fact, preventing primary sensory or supraspinal descending afferent inputs from contacting MTNs in vivo induced the degeneration of $20-35 \%$ of the lumbosacral MTNs between E10 and E16, even though the number of MTNs at the end of the period of physiological MTN death (E10) was not modified (Okado and Oppenheim 1984; Oppenheim et al., 1992). Therefore, it seems reasonable to assume that trophic requirements for MTNs in vitro are covered by MEX up to $6 \mathrm{~d}$. During this time, they could follow a program 
of differentiation similar to that described in vivo and new trophic requirements would develop later. In the case where these requirements were not covered, neurons would die.

The main question addressed in this article is the characterization of MTN death after deprivation of MEX. Oppenheim et al. (1990) have reported that blockade of protein or RNA synthesis in ovo reduced the number of MTNs and dorsal root ganglion cells that degenerate as a consequence of naturally occurring cell death in vivo. The drugs used also prevented neuronal death resulting from the absence of peripheral target. However, this study did not characterize the time course and fine mechanisms that regulate the process of neuronal death. In agreement with previous reports (Martin et al., 1988; Scott and Davies, 1990; Edwards et al., 1991), we have found that macromolecular synthesis is required for neurons to die after trophic deprivation in vitro, implying that this is an active process in which neurons deprived of trophic factor synthesize molecules that would ultimately kill the neurons themselves. The fact that blocking lysosomal function was completely without effect on the process of MTN cell death after deprivation of MEX argues in favor that lysosomal enzymes are not essential for MTN death to occur.

Our ultrastructural analysis of dying MTNs after deprivation of MEX in vitro shows that most of the characteristics that define apoptosis are present in a fraction of dying neurons. These characteristics include condensation of cytoplasm with loss of nuclear membrane and chromatin fragmentation without cytoplasmic membrane disintegration. However, these changes appear asynchronously, with neurons coexisting in very different states of morphological involution at the time we have performed the morphological analysis. These range from healthy looking cells to severely disintegrated ones. From this scenario, we cannot exclude that completely different modes of MTN death exist after deprivation of MEX in vitro, but in such case, at least some of the phases of degeneration of one of those modes is typically apoptotic. Data obtaincd by scoring apoptotic MTNs with a nuclear DNA stain support this view. A considerable increase in the number of neurons showing a highly condensed and fragmented nucleus was observed under MEX deprivation. The condensation and fragmentation of the nuclear chromatin is a very characteristic feature of the apoptotic cell death.

The appearance of a ladder pattern of DNA fragmentation is one of the most important hallmarks of programmed or active cell death (Arends et al., 1990). By using a approach similar to that of Edwards et al. (1991), we have observed a clear pattern of DNA laddering in MTNs deprived of MEX but not in those cultured in the presence of MEX. CHX was able to prevent the appearance of DNA laddering in MTN cultures grown without MEX. This experimental evidence also helps to define the process of MTN death after trophic deprivation as an apoptotic one. Analysis of the temporal pattern of DNA laddering was beyond the scope of the present work. Our results, together with those of Edwards et al. (1991), suggest that the ladder pattern of DNA degradation is a general feature of the process of neuronal death after trophic deprivation.

We have also analyzed the commitment to death in MTNs using several strategies that include readdition of MEX or addition of protein and RNA synthesis blockers at varying times after MEX deprivation. By using these different strategies we have established that after $\sim 10$ hr of MEX deprivation, MTNs become irreversibly committed to death. Fdwards et al. (1990) found that NGF could rescue NGF-deprived sympathetic neu- rons at a significantly later time than $\mathrm{CHX}(\approx 27 \mathrm{hr}$ vs $\approx 15 \mathrm{hr}$, respectively). They interpreted these results on the basis that NGF was able to modulate the activity of the killer proteins at the posttranslational level. However, we and others (Martin et al., 1992) have been unable to find a difference between the commitment points of trophic factors (MEX or NGF) and protein or RNA synthesis blockers. Thus, we think that even though a mechanism of modulating the activity of death proteins may exist, in the case of MTNs, this modulation would not be exerted by the muscle-derived trophic factor itself. Moreover, in light of the conclusion reached by Edwards et al. (1991), one would have expected MEX to rescue at any time MTNs deprived of trophic support but maintained alive by $\mathrm{CHX}$. However, the biphasic survival behavior we report is hardly compatible with such a theory (Fig. 7).

It could be hypothesized that treating MTNs with RNA synthesis inhibitors after MEX deprivation would block the appearance of death genes transcripts inside the deprived neurons. If this was the case, MEX should be able to rescue those MTNs at any time after MEX deprivation provided that MTNs were maintained in a medium containing drugs able to block mRNA transcription. Unfortunately, we have never been successful in reverting the effects of such drugs (ActD, CAMP, and CORD) even after extensive washing of the culture wells; MTNs died after 2-3 d of exposure to any of these drugs, even in the presence of MEX. We interpreted these results as an evidence that RNA synthesis inhibitors result highly toxic for MTNs. Two other independent laboratories (Martin et al., 1988; Scott and Davies, 1990) have reported a similar effect for ActD on other neurons. Martin et al. (1988) reported that sympathetic neurons exposed to ActD for $24 \mathrm{hr}$ were no longer able to incorporate ${ }^{35} \mathrm{~S}$-labeled amino acids into TCA-precipitable protein even after extensive washing of the cultures. Scott and Davies (1990) reported that three different populations of neurons were unable to extend neurites when ActD was washed out from cultures and the appropriate trophic factor was simultancously added. This drawback makes impossible the direct demonstration, by using a pharmacological approach, of transcription of cell death genes upon trophic deprivation in MTNs. An alternative would be to test this hypothesis in other populations of neurons by using drugs such as CAMP that seemed to be less toxic although they are irreversible in MTNs. In experiments in which protein synthesis was blocked by $\mathrm{CHX}$, the effect of $\mathrm{CHX}$ could be reverted by washing the cells. When MEX was used to rescue MTN after they were cultured for varying periods of time in the presence of CHX, MTNs showed a temporal biphasic survival behavior (Fig. 7). Initially (up to $15 \mathrm{hr}$ ), MTNs died when CHX was substituted for MEX. However, from $15 \mathrm{hr}$ onward, neurons became more and more resistant to death when $\mathrm{CHX}$ was replaced by MEX. These experiments may be interpreted on the basis of a temporally limited expression of RNA for toxic proteins. Up to $15 \mathrm{hr}$ of deprivation, MEX would not be able to revert the death program because mRNA molecules for toxic proteins would accumulate in the cells as a consequence of trophic deprivation. As protein blockade caused by CHX was released, mRNA would translate into functional proteins and cause cell death. However, from $15 \mathrm{hr}$ onward we found that MEX was able to rescue most MTNs from death. Therefore, we postulate that after $15 \mathrm{hr}$, at lcast one of the essential mRNAs implicated in the gene expression of the death program would no longer be transcribed.

The idea we postulate here that the activation of the neuronal 
death program upon trophic deprivation is transient and allows room for imagining the existence of a mechanism that would enable neurons to bypass neuronal death temporally. It is known that high potassium and membrane-permeant cAMP analogs can rescue from death a wide variety of neurons (reviewed by Franklin and Johnson, 1992), including MTNs (Comella, SanzRodriguez, Aldea, and Esquerda, unpublished observations) presumably by activating second messengers that differ, at least partially, from those activated by neurotrophins. These mechanisms would enable neurons to become independent of trophic factor at least temporally. If this independence of trophic support lasted past the transient expression of mRNA molecules for death genes upon trophic deprivation, neurons would then be able to reenter the trophic program as they regained access to neurotrophic factor, making this mechanism the last safety resort before irreversible neuronal death.

One important issue that remains to be elucidated in this context is the molecular characterization and quantification of the neuron-specific cell death genes. The increased expression of several genes has been described in tissues that undergo apoptosis (Fesus et al., 1987; Leger et al., 1987; Buttyan et al., 1988; Buttuzzi et al., 1989; Kyprianou and Isaacs, 1989; Schwartz et al., 1990; Goldstone and Lavin, 1991; Owens et al., 1991; Strange et al., 1992). However, the mRNA quantization of those death genes in dying sympathetic neurons after NGF withdrawal has not shown any significant alteration (Martin et al., 1992; D'Mello and Galli, 1993), thus suggesting that the genes implicated in the death process in neurons are probably different. With the present characterization of programmed cell death in MTNs and, keeping in mind the suggested transient expression of mRNA for killing proteins in these neurons, we are currently approaching the molecular characterization of these genes by means of subtractive hybridization techniques.

\section{References}

Altman J (1992) Programmed cell death: the paths to suicide. Trends Neurosci 15:278-280.

Arakawa Y, Sendtner M, Thoenen H (1990) Survival effect of ciliary neurotrophic factor (CNTF) on chick embryonic motoneurons in culture: comparison with other neurotrophic factors and cytokines. J Neurosci 10:3507-3515.

Arends MJ, Morris RG, Wyllie AH (1990) Apoptosis. The role of the endonuclease. Am J Pathol 136:593-608.

Barde YA (1989) Trophic factors and neuronal survival. Neuron 2:1525-1534

Bloch-Gallego E, Huchet M, El M'Hamdi H, Xie FK, Tanaka H, Henderson CE (1991) Survival in vitro of motoneurons identified or purified by novel antibody-based methods selectively enhanced by muscle-derived factors. Development 111:221-232.

Bradford $M$ (1976) A rapid and sensitive method for quantification of microgram quantities of protein utilizing the principle of proteindye binding. Anal Biochem 72:248-253.

Buttuzzi S, Hiipakka RA, Gilna P, Liao S (1989) Identification of an androgen-repressed mRNA in ventral prostate as coding for sulphated glycoprotein 2 by cDNA cloning and sequence analysis. Biochemical J 257:293-296.

Buttyan R, Zakari Z, Lockshin R, Wolgemuth D (1988) Cascade induction of $c$-fos, $c$ - $m y c$, and heat-shock $70 \mathrm{~K}$ transcripts during regression of a rat ventral prostate gland. Mol Endocrinol 2:650-657.

Caroni P, Grandes P (1990) Nerve sprouting in innervated adult skeletal muscle induced by exposure to elevated levels of insulin-like growth factors. J Cell Biol 110:1307-1317.

Chao MV (1992) Growth factor signaling: where is the specificity? Cell 68:995-997.

Comella JX, Sanz-Rodriguez C, Esquerda JE (1992) Inhibitors of protein and RNA synthesis prevent motoneuron cell death after trophic deprivation in vitro. Soc Neurosci Abstr 18:51.
DiStefano PS, Schweitzer JB, Taniuchi M, Johnson EM Jr (1985) Selective destruction of nerve growth factor receptor-bearing cells in vitro using a hybrid toxin composed of ricin $A$ chain and a monoclonal antibody against the nerve growth factor receptor. J Cell Biol 101: 1107-1114.

D'Mello SR, Galli C (1992) SGP2, ubiquitin, 14K lectin and RP8 messenger RNAs are not induced in neuronal apoptosis. Neuroreport $4: 355-358$.

Dohrmann U, Edgar D, Sendtner M, Thoenen H (1986) A musclederived factor that supports survival and promotes fiber outgrowth from embryonic chick spinal motor neurons in culture. Dev Biol 118: 209-221.

Dohrmann U, Edgar D, Thoenen H (1987) Distinct neurotrophic factors from skeletal muscle and the central nervous system interact synergistically to support the survival of cultured embryonic spinal motor neurons. Dev Biol 124:145-152.

Ebendal T (1992) Function and evolution in the NGF family and its receptors. J Neurosci Res 32:461-470.

Edwards SN, Buckmaster AE, Tolkovsky AM (1991) The death programme in cultured sympathetic neurones can be suppressed at the posttranslational level by growth factor, cyclic AMP, and depolarization. J Neurochem 57:2140-2143.

Fesus L, Thomazy V, Falus A (1987) Induction and activation of tissue transglutaminase during programmed cell death. FEBS Lett 224:104-108.

Flanigan TP, Dickson JG, Walsh FS (1985) Cell survival characteristics and choline acetyltransferase activity in motor neurone-enriched cultures from chick embryo spinal cord. J Neurochem 45:1323-1326.

Fonnum $F$ (1975) A rapid radiochemical method for the determination of choline acetyltransferase. J Neurochem 24:407-409.

Franklin JL, Johnson EM Jr (1992) Suppression of programmed neuronal death by sustained elevation of cytoplasmic calcium. Trends Neurosci 15:501-508.

Goldstone SD, Lavin MF (1991) Isolation of a cDNA clone, encoding a human beta-galactosidase binding protein, overexpressed during glucocorticoid-induced cell death. Biochem Biophys Res Commun 178:746-750.

Hamburger V (1975) Cell death in the development of the lateral motor column of the chick embryo. J Comp Neurol 160:535-546.

Henderson CE, Huchet M, Changeux JP (1983) Denervation increases a neurite-promoting activity in extracts of skeletal musclc. Naturc 302:609-611.

Henderson CE, Camu W, Mettling C, Gouin A, Poulsen K, Karihaloo M, Rullamas K, Evans T, McMahon SB, Armanini MP, Berkheimer L, Phillips HS, Rosenthal A (1993) Neurotrophins promote motor neuron survival and are present in embryonic limb bud. Nature 363: $266-270$

Houenou LJ, McManaman JL, Prevette D, Oppenheim RW (1991) Regulation of putative muscle-derived neurotrophic factors by muscle activity and innervation: in vivo and in vitro studies. J Neurosci 11 : 2829-2837.

Hughes RA, Sendtner M, Goldfarb M, Lindholm D, Thoenen H (1993) Evidence that fibroblast growth factor 5 is a major muscle-derived survival factor for cultured spinal motoneurons. Neuron 10:369-377.

Jeong SO, Oh TH, Markelonis GJ (1991) A neurite-promoting factor from muscle supports the survival of cultured chicken spinal motor neurons. J Neurobiol 22:462-474.

Johnson EM Jr, Deckwerth TL (1993) Molecular mechanisms of developmental neuronal death. Annu Rev Neurosci 16:31-46.

Johnson EM Jr, Chang JY, Koike T, Martin DP (1989) Why do neurons die when deprived of trophic factor? Neurobiol Aging 10: 549-552.

Juurlink BHJ, Munoz DG, Ang LC (1991) Motoneuron survival in vitro: effects of pyruvate, $\alpha$-ketoglutarate, gangliosides and potassium. Neurosci Lett 133:25-28.

Kerr JRF, Wyllie AII, Currie AR (1972) Apoptosis: a basic biological phenomenon with wide-ranging implications in tissue kinetics. $\mathrm{Br} \mathrm{J}$ Cancer 26:239-257.

Koliatsos VE, Clatterbuck RE, Winslow JW, Cayouette RE, Price DL (1993) Evidence that brain-derived neurotrophic factor is a trophic factor for motor neurons in vivo. Neuron 10:359-367.

Kyprianou N, Isaacs JT (1989) Expression of transforming growth factor in the rat ventral prostate during castration induced programmed cell death. Mol Endocrinol 3:1515-1522.

Lee MT, O’Donovan MJ (1991) Organization of hindlimb muscle 
afferent projections to lumbosacral motoneurons in the chick embryo. J Neurosci 11:2564-2573.

Leger JG, Montpetit ML, Tenniswood MP (1987) Characterization and cloning of androgen-repressed mRNA from ventral prostate. Biochem Biophys Res Commun 147:196-203.

Lo DC (1992) Signal transduction and regulation of neurotrophins. Curr Opin Neurobiol 2:336-340.

Martin DP, Johnson EM Jr (1991) Programmed cell death in the peripheral nervous system. In: Current communications in cell and molecular biology, Vol 3, Apoptosis: the molecular basis of cell death (Tomei LD, Cope FO, eds), pp 247-261. Cold Spring Harbor, NY: Cold Spring Harbor Laboratory.

Martin DP, Schmidt RE, DiStefano PS, Lowry OH, Carter JG, Johnson EM Jr (1988) Inhibitors of protein synthesis and RNA synthesis prevent neuronal death caused by nerve growth factor deprivation. J Cell Biol 106:829-844.

Martin DP, Ito A, Horigome K, Lampe PA, Johnson EM Jr (1992) Biochemical characterization of programmed cell death in NGF-deprived sympathetic neurons. J Neurobiol 23:1205-1220.

Martinou JC, Le Van Thai A, Cassar G, Roubinet F, Weber M (1989) Characterization of two factors enhancing choline acetyltransferase activity in cultures of purified rat motor neurons. J Neurosci 9:36453656.

Martinou JC, Martinou I, Kato AC (1992) Cholinergic differentiation factor (CDF/LIF) promotes survival of isolated rat embryonic motoneurons in vitro. Neuron 8:737-744.

McManaman JL, Oppenhcim RW, Prevette D, Marchetti D (1990) Rescue of motoneurons from cell death by a purified skeletal muscle polypeptide: effects of the ChAT developmental factor, CDF. Neuron 4:891-898

O'Brien RJ, Fischbach GD (1986) Isolation of embryonic chick motoneurons and their survival in vitro. J Neurosci 6:3265-3274.

Okado N, Oppenheim RW (1984) Cell death of motoneurons in the chick embryo spinal cord. IX. The loss of motoneurons following removal of afferent inputs. J Neurosci 4:1639-1652.

Oppenheim RW (1975) The role of supraspinal input in embryonic motility: a re-examination in the chick. J Comp Neurol 160:37-50.

Oppenheim RW (1989) The neurotrophic theory and naturally occurring motoneuron death. Trends Neurosci 12:252-255.

Oppenheim RW (1991) Cell death during development of the nervous system. Annu Rev Neurosci 14:453-501.

Oppenheim RW, Heaton MB (1975) The retrograde transport of horseradish peroxidase from the developing limb of the chick embryo. Brain Res 98:291-302.

Oppenheim RW, Haverkamp LJ, Prevette D, McManaman JL, Appel SH (1988) Reduction of naturally occurring motoneuron death in the chick embryo in vivo by a target-derived neurotrophic factor. Science 240:919-922.

Oppenheim RW, Prevette DM, Tytell D, Homma S (1990) Naturally occurring and induced neuronal death in vivo requires protein and RNA synthesis: evidence for the role of cell death genes. Dev Biol 138:104-113

Oppenheim RW, Qin-Wei Y, Prevette D, Yan Q (1992) Brain-derived neurotrophic factor rescues developing avian motoneurons from cell death. Nature 360:755-757.

Owens GP, Hahn WE, Cohen IJ (1991) Identification of mRNAs associated with programmed cell death in immature thymocytes. Mol Cell Biol 11:4177-4188.

Pelech SL, Sanghera JS (1992) MAP kinases: charting the regulatory pathways. Science 257:1355-1356.

Raff MC (1992) Social controls of cell survival and cell death. Nature $356: 397-400$

Rassendren FA, Bloch Gallego E, Tanaka H, Henderson CE (1992) Levels of messenger RNA coding for motoneuron growth-promoting factors are increased in denervated muscle. Proc Natl Acad Sci USA 89:7194-7198.

Raynaud B, Faucon-Biguet N, Vidal S, Mallet J, Michel MJ (1987) The use of a tyrosine hydroxylase cDNA probe to study the neurotransmitter plasticity of rat sympathetic neurons in culture. Dev Biol 119:305-312.

Roberts TM (1992) A signal chain of events. Nature 360:534-535.

Schnaar RL, Schaffner AZ (1981) Separation of cell types from embryonic chicken and rat spinal cord: characterization of motoneuronenriched fractions. J Neurosci 1:204-217.

Schwartz LM, Myer A, Kosz L, Engelstein M, Maier C (1990) Activation of polyubiquitin gene expression during developmentally programmed cell death. Neuron 5:411-419.

Scott SA, Davies AM (1990) Inhibition of protein synthesis prevents cell death in sensory and parasympathetic neurons deprived of neurotrophic factor in vitro. J Neurobiol 21:630-638.

Sendtner M, Holtmann B, Kolbeck R, Thoenen H, Barde YA (1992) Brain-derived neurotrophic factor prevents the death of motoneurons in new born rats after nerve section. Nature 360:753-755.

Snider WD, Johnson EM Jr (1989) Neurotrophic molecules. Ann Neurol 26:489-506.

Strange R, Li F, Saurer S, Burkhardt A, Fris RR (1992) Apoptotic cell death and tissue remodelling during mouse mammary gland involution. Development 115:49-58.

Tanaka H (1987) Chronic application of curare does not increase the lcvels of motoneuron survival-promoting activity in limb muscle extracts during the naturally occurring motoneuron cell death period. Dev Biol 124:347-357.

Tanaka H, Obata K (1984) Developmental changes in unique cell surface antigens of chick embryo spinal motoneurons and ganglion cells. Dev Biol 106:26-37.

Yan Q, Elliot J, Snider WD (1992) Brain-derived neurotrophic factor from axotomy-induced cell death. Nature 360:753-755. 